\title{
MODEL KOMUNIKASI JARINGAN
}

\section{Santy Karina}

175100051

\section{Santy karina.student@umitra.ac.id}

\section{Universitas Mitra Indonesia}

\begin{abstract}
ABSTRAK
Komunikasi sangat dibutuhkan untuk interaksi sesama manusia, oleh karena itu komunikasi tidak dapat dipisahkan dari kehidupan manusia sehari-hari, sehingga tanpa adanya komunikasi, kehidupan manusia tidak akan berjalan dengan sempurna. Karena komunikasi itu memiliki peranan sangat penting, dibuatlah suatu model komunikasi.

Komunikasi memiliki beberapa model, dan setiap modelnya memiliki definisi yang berbeda pula. Model komunikasi dibuat supaya mempermudah dalam memahami proses komunikasi dan melihat komponen dasar yang perlu ada dalam suatu komunikasi. Komunikasi juga merupakan suatu proses. Hal ini terlihat dari setiap gejala atau peristiwa yang tidak luput dari adanya suatu komunikasi yang terjalin antarmanusia.

Dalam makalah ini, kami menjelaskan beberapa model komunikasi yang didefinisikan oleh para ahli dan juga menjelaskan tentang komunikasi sebagai proses.
\end{abstract}

\section{A.CAPTURE PROGRAM}

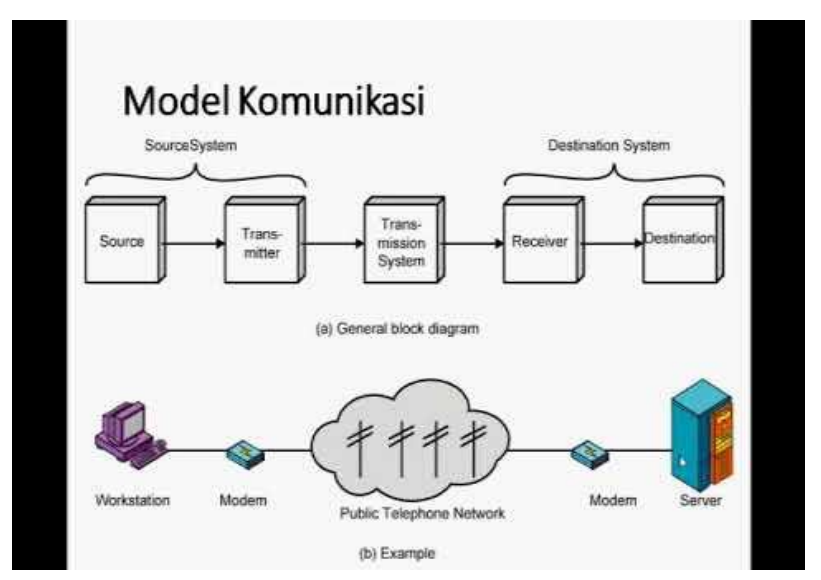




\section{B.PENJELASAN}

Model komunikasi adalah gambaran yang sederhana dari proses komunikasi yang memperlihatkan kaitan antara satu komponen komunikasi dengan komponen lainnya.Menurut Sereno dan Mortensen, suatu Model komunikasi merupakan deskripsi ideal mengenai apa yang dibutuhkan untuk terjadinya komunikasi. Suatu model merepresentasikan secara abstrak ciri-ciri penting dan menghilangkan rincian komunikasi yang tidak perlu dalam "dunia nyata".Aubrey Fisher mengatakan, Model adalah analogi yang mengabstraksikan dan memilih bagian dari fenomena yang dijadikan model

Werner J. Severin dan James W. Tankard, Jr. mengatakan bahwa Model membantu merumuskan suatu teori dan menyarankan hubungan. Oleh karena hubungan antara model dengan teori begitu erat, model sering dicampur dengan teori.

suatu alat (saluran, media, rekayasa fisik, fasilitas administrative, dan kelembagaanuntuk distribusidan control) untuk menyediakan materi dalam suatu bentuk dan konteks yang mengandung isi dengan konsekuensi yang ada.Model Diagramatik : Seseorang mempersepsi kejadian dan mengirim beberapa pesan untuk pemancar yang akan mengirim sinyal kepada penerima. Pada transmisi ini, sinyal akan menghadapi gangguan dan menjadi SSSE untuk si tujuan.

\section{C.DISKUSI}

Komunikasi yang efektif adalah bagian utama dalam mencapai tujuan pendidikan.Komunikasi yang sukses dan efektif berasal dari pelaksanaan proses komunikasi. Orang-orang yang terlibat akan meningkatkan keterampilan komunikasi mereka jika mereka mengikuti proses komunikasi, dan tinggal jauh dari hambatan yang berbeda. Telah terbukti bahwa individu yang memahami proses komunikasi akan berkembang menjadi komunikator yang lebih efektif, dan komunikator yang efektif memiliki kesempatan lebih besar untuk menjadi sukses.Oleh karena itu kita harus menggunakan model-model komunikasi yang pas dalam berkomunikasi.

\section{REFERENSI}

[1] A. S. Putra And O. M. Febriani,

"Knowledge Management

Online Application In Pdam

Lampung Province,” In 
Prosiding International

Conference On Information

Technology And Business

(Icitb), 2018, Pp. 181-187.

[2] A. S. Putra, O. M. Febriani, And

B. Bachry, "Implementasi

Genetic Fuzzy System Untuk

Mengidentifikasi Hasil Curian

Kendaraan Bermotor Di Polda

Lampung," J. Sist. Inf. Dan

Manaj. Basis Data, Vol. 1, No.

1, Pp. 21-30, 2018.

[3] O. M. Febriani And A. S. Putra,

"Sistem Informasi Monitoring

Inventori Barang Pada Balai

Riset Standardisasi Industri

Bandar Lampung," J. Inform.,

Vol. 13, No. 1, Pp. 90-98, 2014

[4] Putra, Arie Setya. "2018 Artikel

Struktur Data, Audit Dan

Jaringan Komputer." (2018).

[5] Putra, A. S. (2018, July 17).

Paperplain Fundamental Create

Application With Borland

Delphi 7.0 University Of Mitra

Indonesia. Retrieved From

Osf.Io/Pbrn9. 
